Author: Kamil Anasiewicz

Title of article: „Dokładność geometryczna naroży po obróbce frezowaniem stopów aluminium” (“Geometric accuracy of corners after milling operation of aluminum alloys")

Mechanik, Vol. 91, No. 10 (2018): pages 862-864

DOI: https://doi.org/10.17814/mechanik.2018.10.145

\title{
Geometric accuracy of corners after milling operation of aluminum alloys
}

\author{
Dokładność geometryczna naroży \\ po obróbce frezowaniem stopów aluminium
}

\section{KAMIL ANASIEWICZ *}

The study comparing a geometry of the inner corners after milling operation of aluminum alloy 7075 elements was conducted. The influence of changes of technological parameters and types of treatment on the geometric accuracy of the samples was investigated. The correct process of corner milling involves the need to select the right feed speed as well as the correct engagement angle of the milling tool. Corner milling is problematic due to the increase of engagement angle in their area. This makes it much more difficult to perform stable machining and adversely affects the surface accuracy and geometry of the concave corners. The tests using various strategies and technological parameters for milling corners with variable opening angles were carried out. When analyzing the obtained results, conclusions were formulated indicating the relationship between the change of selected technological parameters of milling in the corners and the geometric accuracy of the samples tested.

KEYWORDS: geometric accuracy, corner machining, corner milling, machining

The main purpose of the presented study was to assess the impact of variable technological parameters on the geometric accuracy of the milled corner. The tests were carried out on a three-axis vertical machining center. Samples of aluminum alloy 7075 were used. Various technological parameters and types of machining were applied. Machining with corner milling makes trouble because of the increased tool engagement angle. The problem becomes particularly evident when machining casting molds, forging, blow molding or thin-walled pocket constructions used for the aviation industry [1, 2]. In this type of elements there are small radii of corner roundings, often located in deep pocket openings, which requires large overhangs of the tool and may prevent the use of a smaller diameter tool.

In modern processing technologies, such as HSM and HSC, full control over the parameters is necessary [3, 4]. The adoption of inadequate parameters results in deterioration of surface quality and even undercutting of the corner surface. Increasing engagement angle in the corners results in an increase in the required cutting power and causes vibration, which can accelerate the wear of the spindle and tools and increase its deflection [5-7]. Requirements regarding the accuracy and quality of the surface of the execution of such forms are usually very high. An appropriate strategy for machining corners can allow to significantly reduce or eliminate the need for manual lapping or grinding zones in the corners [8,9].

The research presented in the literature [2, 9] discussed the problem of machining pocket seams and their corners, however, the focus was not on measuring the geometrical accuracy of their execution. Often in small diameter corners - due to geometrical constraints - it is impossible to use a smaller diameter tool that would reduce the wrap angle. For this reason, it is important to adopt an appropriate strategy for their treatment, which will not adversely affect its performance.

\section{Description of the method}

The tests of machining corners with different opening angles of $60^{\circ}, 75^{\circ}, 90^{\circ}$ and $105^{\circ}$, with a radius of rounding $r$ $=5 \mathrm{~mm}$, using different types and machining strategies were carried out. Each corner was roughed, semi-finished and finished. In addition, a feed reduction strategy in the corners was applied for each type of machining.

Samples made of aluminum alloy 7075 were milled in a rigid mounting on a Hwacheon Vesta 1000 three-axis milling machine. The tests were performed with a carbide milling cutter WNT No. 53518100. The tool had a diameter of $\varnothing 10$ $\mathrm{mm}$, three working blades, helix angle $\lambda_{\mathrm{s}}=45^{\circ}$, and angle of attack $y=8^{\circ}$. The depth of cut was $a_{p}=15 \mathrm{~mm}$ including allowances between operations. CNC program was developed using CAD/CAM NX 8.5 software. The cutting speed for roughing and semi-finishing operations was $V_{\mathrm{c}}=$ $300 \mathrm{~m} / \mathrm{min}$, and feed rate $-0.08 \mathrm{~mm} /$ blade in operations without feed change at the corners. After roughing operation, a $1 \mathrm{~mm}$ allowance was left. In the case of specimens in which the feed at the corners was reduced, a setting was applied that allowed gradual reduction of the tool feed to $50 \%$ in seven steps at the moment the tool entered the corner.

The cutting speed for the finishing operation was $V_{c}=$ $450 \mathrm{~m} / \mathrm{min}$, and the basic feed was $0.06 \mathrm{~mm} / \mathrm{blade}$. After the semi-finished operation, $0.15 \mathrm{~mm}$ of finishing allowance was removed in the finishing treatment.

Corner geometry measurements were made using the Keyence VHX-5000 digital microscope (fig. 1).

\footnotetext{
* Mgr inż. Kamil Anasiewicz (k.anasiewicz@pollub.pl) - Politechnika
} 




Fig. 1. Corner measurement on a digital microscope

The measurements included checking the undercuts created during milling and measuring the geometry of the obtained corners. Measurements were made parallel to the corner wall, using a magnification of 100x.

\section{Results}

Measurements made on a digital microscope allow to evaluate the geometrical accuracy of the treatment and detect unwanted phenomena. They indicate unambiguously that in all examined corner angle values in semi-finishing machining the corners were cut (fig. 2). The undercut of the corner is understood as a geometrical inaccuracy caused by pulling the tool inside the corner. This causes an undesirable change in the profile in relation to the programmed geometry. The corner machining with a tool with a diameter corresponding to the radius of the processed corner is particularly exposed to the occurrence of undercuts.

The presented results include samples made using semifinishing.

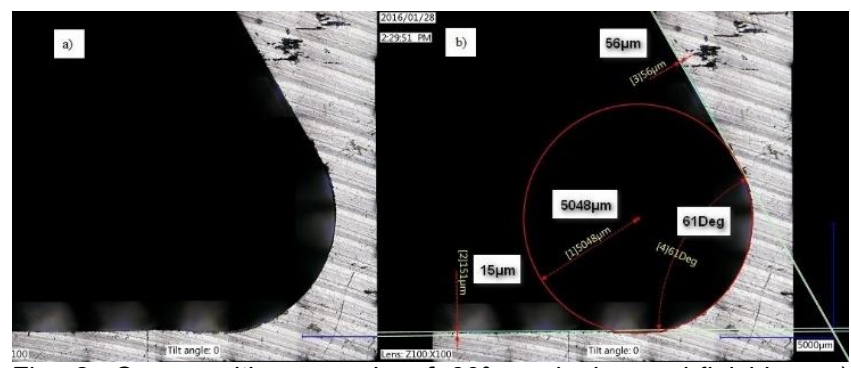

Fig. 2. Corner with an angle of $60^{\circ}$ made in semi-finishing: a) without dimensions, $b$ ) with dimensions

Fig. 3 presents the results of the value of the corner undercut with an angle of $60^{\circ}$ in relation to the expected value for semi-finishing (SF) and semi-finishing with release of feed per tooth at the corners (SF SDC). Based on the analysis of the graph, it can be seen that the use of machining strategies with the feed release on the blade at the corners allows for almost half the value of the corner undercut - both on the input and output sides. Reducing the feed rate by $50 \%$ in relation to the basic value allows to significantly reduce the corner undercut, especially when it is not possible to use a smaller tool.

In the case of corner angle $75^{\circ}$, you can notice a decrease in undercuts (fig. 4). In addition, the application of feed reduction strategy in the corners (SF SDC) allowed for almost twice reducing the undercut when entering the cutter and eliminating it during the exit of the tool.

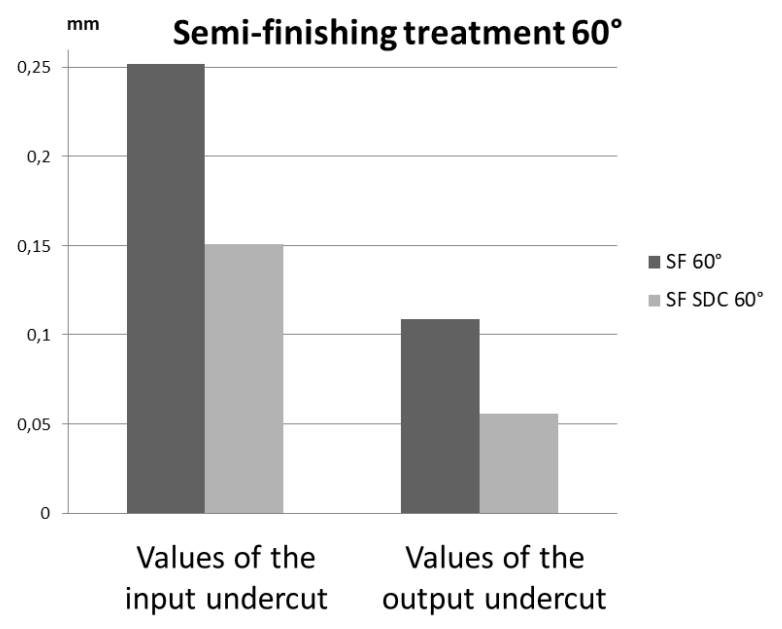

Fig. 3. Comparison of data from semi-finishing with constant feedrate (SF) and deceleration of feed in corners (SF SDC) at $60^{\circ}$

\section{$\mathrm{mm} \quad$ Semi-finishing treatment $75^{\circ}$}

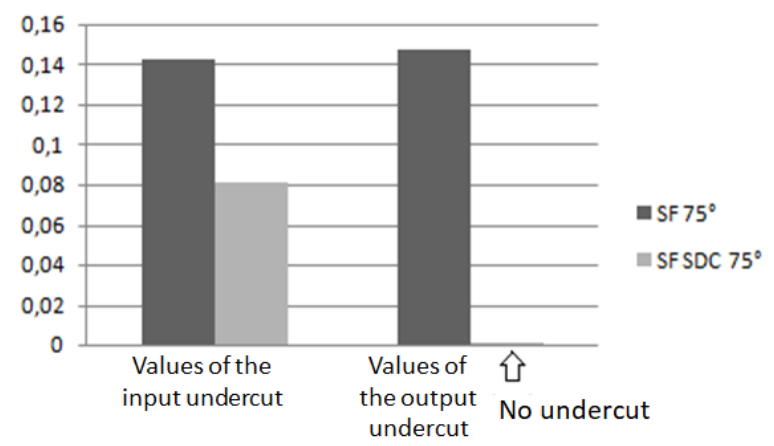

Fig. 4. Comparison of post-processing with a constant feed rate and feed release at the corners for $75^{\circ}$

Based on the carried out measurements of the angle of $90^{\circ}$ (fig. 5), it can be noticed continuation of the undercutting value reduction. With respect to the previous corner angle, the undercutting values are smaller. Both when machining with constant feed and machining with feed reduction at the corners do not undercut the corner when the tool exits from its zone.

For a corner with an obtuse angle of $105^{\circ}$ (fig. 6) and a right angle, the undercutting of the corner occurs only at the entrance. The undercutting values are over $50 \%$ lower for machining with constant feed in relation to the corner angle of $60^{\circ}$. Application of the SDC strategy allowed to reduce the undercutting at the entrance by as much as $65 \%$.

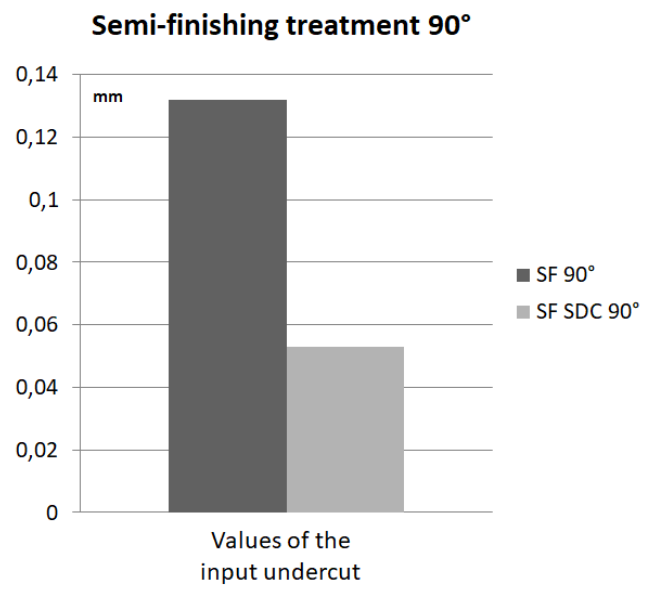

Fig. 5. Comparison of post-processing with a constant feed rate and feed reduction at the corners for a $90^{\circ}$ angle 


\section{Semi-finishing treatment $105^{\circ}$}



Fig. 6. Comparison of finishing machining with a constant feed rate and feed release at the corners for $105^{\circ}$

\section{Summary of values of corners undercut}

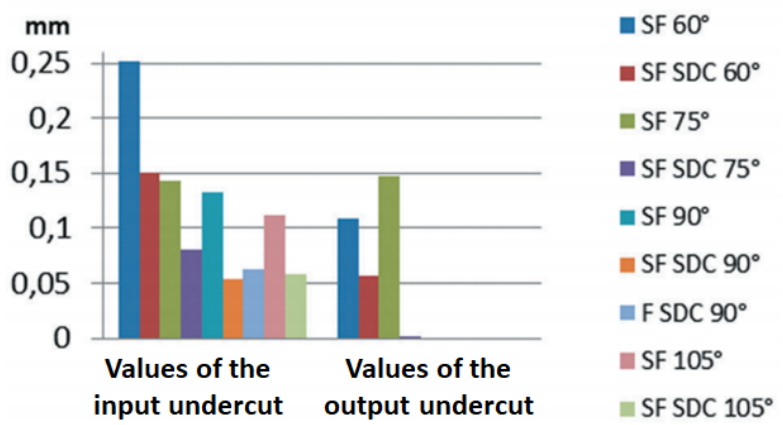

Fig. 7. Graph comparing all existing undercut corners with input and output values

Fig. 7 lists the measurements of input and output undercuts for all tested corner angles and the strategies used.

In addition, during corner milling with a $90^{\circ}$ straight angle, its undercutting took place in the finishing operation. Measured values of corner angles are consistent with the assumptions or deviate from them by a maximum of $\pm 1^{\circ}$.

The accuracy of the assumed radius of the internal corner was also measured. In semi-finished machining, the differences in the values of the obtained corner radii are relatively small, at most $2.5 \%$ from the planned corner radius of $5 \mathrm{~mm}$.



Fig. 8. Corner with an angle of $75^{\circ}$ made in the finishing treatment: a) without dimensions, $b$ ) with the dimensions

\section{Conclusions}

As a result of the research, the assumptions formulated in the introduction of the work were verified. It can be concluded that there is a relationship between the change of selected technological parameters and the obtained quality parameters of the samples made.

The following conclusions can be drawn:

- In all samples tested, the corner was cut due to the tool being pulled into the corner. The undercut at the entrance is much more common than the undercut at the exit. Changing the corner profile in the area of undercutting is undesirable.

- The corner machining with a tool with a diameter corresponding to the radius of the corner being made is particularly vulnerable to the occurrence of undercuts.

- In the extreme case, the value of the corner entry undercut was $0.25 \mathrm{~mm}$, but it was reduced to $0.15 \mathrm{~mm}$ thanks to the strategy of feed reduction in the corners.

- The use of cutting strategy on the blade at the corner significantly limits the creation of undercuts and reduces the amount of such undercutting by up to $65 \%$ in the zone of entry to the corner and exit from it.

- Strategy of reducing the feed to the blade at the corners does not adversely affect the time and efficiency of the machining.

Due to the results obtained, it is recommended to reduce the speed of the work feed when entering the tool into the corner. Program paths of the tool to obtain the smallest possible tool angle. If possible, tools with a radius less than the radius of the milled corner should be used.

\section{REFERENCES}

1. Burek J., Płodzień M. „Wysokowydajna obróbka części ze stopów aluminium o złożonych kształtach". Mechanik. 7 (2012): pp. 542-549.

2. Choy H.S., Chan K.W. "Machining tactics for interior corners of pockets". IJAMT. 20, 10 (2002): pp. 741-748.

3. Kłonica M., Kuczmaszewski J., Matuszak J., Pałka T., Pieśko P., Rusinek R., Włodarczyk M., Zagórski I., Zaleski K. „Obróbka skrawaniem stopów aluminium i magnezu". Lublin: Politechnika Lubelska (2015).

4. Oczoś K.E., Kawalec A. „Kształtowanie metali lekkich”. Warsaw: Wydawnictwo Naukowe PWN (2012).

5. Pieśko P. „Badania wpływu sztywności statycznej frezów trzpieniowych na dokładność geometryczną przedmiotów wykonanych ze stopów aluminium. Ph.D. (February 2014).

6. Pieśko P., Zagórski I. „Analiza porównawcza metod frezowania HSM, HPC oraz frezowania konwencjonalnego wysokokrzemowych stopów aluminium". Postępy Nauki i Techniki. 7 (2011): pp. 219-226.

7. Tsui K.S. Chan K.W. "An efficient NC tool path planning approach". ICCIMA 2005: $6^{\text {th }}$ International Conference on Computational Intelligence and Multimedia Applications, Proceedings. (2005): pp. 132-137.

8. Wei Z., Wang M.J., Han X.G. "Cutting forces prediction in generalized pocket machining". IJAMT. 50, 5 (2010): pp. 449458.

9. Yue Caixu, Liu Xianli, Ding Yunpeng, Liang S. "Off-line error compensation in corner milling process". Proceedings of The Institution of Mechanical Engineers Part B - Journal of Engineering Manufacture. 232, 7 (2016): pp. 1172-1181. .

Translation of scientific articles, their computer composition and publishing them on the website www.mechanik.media.p by original articles in Polish is a task financed from the funds of the Ministry of Science and Higher Education designated for dissemination of science. 